Acta Crystallographica Section B

Structural

Science

ISSN 0108-7681

\section{Samuel M. Hawxwell, Harry} Adams and Lee Brammer*

Department of Chemistry, University of Sheffield, Brook Hill, Sheffield S3 7HF, England

Correspondence e-mail: lee.brammer@sheffield.ac.uk
(C) 2006 International Union of Crystallography

Printed in Great Britain - all rights reserved

\title{
Two-dimensional metal-organic frameworks containing linear dicarboxylates
}

The solvothermal synthesis of four two-dimensional metalorganic frameworks containing linear dicarboxylic acids as ligands for $\mathrm{Zn}^{\mathrm{II}}$ centres is described. $\mathrm{Zn}(\mathrm{BDC})(\mathrm{DMF})[(1)$ where $\mathrm{BDC}=$ benzene-1,4-dicarboxylic acid; $\mathrm{DMF}=\mathrm{N}, \mathrm{N}$ dimethylformamide] adopts a common paddlewheel motif leading to a $4^{4}$ grid network, whereas $\mathrm{Zn}_{3}(\mathrm{BDC})_{3}(\mathrm{EtOH})_{2}(2)$, $\mathrm{Zn}_{3}(\mathrm{BDC})_{3}\left(\mathrm{H}_{2} \mathrm{O}\right)_{2} \cdot 4 \mathrm{DMF}$ (3) and $\mathrm{Zn}_{3}(\mathrm{BPDC})_{3}(\mathrm{DMF})_{2} \cdot-$ $4 \mathrm{DMF}$ (4) each form networks with the relatively uncommon $3^{6}$ topology based upon $\mathrm{Zn}_{3}\left(\mathrm{O}_{2} \mathrm{CR}\right)_{6}$ secondary building units. All contain coordinated solvent molecules, namely DMF [(1) and (4)], ethanol (2) or $\mathrm{H}_{2} \mathrm{O}$ (3). Comparison of structures (2) and (3) illustrates a clay-like flexibility in interplanar spacing which sheds light on the ability of the $\mathrm{Zn}_{3}(\mathrm{BDC})_{3}$ framework to undergo desolvation and uptake of small solvent and gas molecules.

\section{Introduction}

Research concerning metal-organic frameworks (or coordination networks) has become increasingly important in recent years (Kitagawa et al., 2004; Eddaoudi et al., 2001; Janiak, 2003; James, 2003; Rowsell \& Yaghi, 2004; Lin, 2005) owing to their potential application in a number of areas, including gas storage (Noro et al., 2000; Eddaoudi et al., 2002; Férey et al., 2003; Rowsell et al., 2004) and catalysis (Fujita et al., 1994; Seo et al., 2000; Wu et al., 2005). Prominent among this class of materials are frameworks that involve dicarboxylate ligands spanning network nodes, comprising one or more (transition) metal ions. An advantage of this approach over methods using neutral ligands such as 4,4-bipyridyl to link metal centres is that the anionic dicarboxylate ligand typically leads to networks in which it is not necessary to accommodate other counterions to achieve electroneutrality.

The simplest type of linear aromatic dicarboxylic acid is terephthalic acid (benzene-1,4-dicarboxylic acid; BDC), and this has been used extensively in the synthesis of metalorganic frameworks. Indeed, terephthalic acid was the first acid reported by Yaghi and coworkers in the series of structures subsequently referred to as isoreticular metal-organic frameworks (IRMOFs; Li et al., 1999). We report here the syntheses and crystal structures of three two-dimensional zincBDC metal-organic frameworks: $\mathrm{Zn}(\mathrm{BDC})(\mathrm{DMF})$ (1); $\mathrm{Zn}_{3}(\mathrm{BDC})_{3}(\mathrm{EtOH})_{2}(2) ; \mathrm{Zn}_{3}(\mathrm{BDC})_{3}\left(\mathrm{H}_{2} \mathrm{O}\right)_{2} \cdot 4 \mathrm{DMF}$ (3); and also a two-dimensional framework containing the extended dicarboxylate linker 4,4-biphenyldicarboxylate (BPDC): $\mathrm{Zn}_{3}(\mathrm{BPDC})_{3}(\mathrm{DMF})_{2} \cdot 4 \mathrm{DMF}(4)$. The square-grid $\left(4^{4}\right)$ structure of (1) is constructed from the common $M_{2}\left(\mathrm{O}_{2} \mathrm{CR}\right)_{4}$ paddlewheel motif. Structures (2), (3) and (4) are isoreticular and all adopt the relatively uncommon $3^{6}$ network involving $M_{3}\left(\mathrm{O}_{2} \mathrm{CR}\right)_{6}$ nodes.
Received 14 June 2006 Accepted 18 August 2006 
Table 1

Experimental details.

(1)

Crystal data

Chemical formula

$M_{r}$

Cell setting, space group

Temperature (K)

$a, b, c(\AA)$

$\alpha, \beta, \gamma\left(^{\circ}\right)$

$V\left(\AA^{3}\right)$

$Z$

$D_{x}\left(\mathrm{Mg} \mathrm{m}^{-3}\right)$

Radiation type, wavelength

$\mu\left(\mathrm{mm}^{-1}\right)$

Crystal form, colour

Crystal size (mm)

Data collection

Diffractometer

Data collection method

Absorption correction

$T_{\min }$
$T_{\max }$
No. of measured, indepen-
$\quad$ dent and observed
reflections
Criterion for observed
$\quad$ reflections
$R_{\text {int }}$
$\theta_{\max }\left({ }^{\circ}\right)$

Refinement

Refinement on

$R\left[F^{2}>2 \sigma\left(F^{2}\right)\right], w R\left(F^{2}\right), S$

No. of reflections

No. of parameters

$\mathrm{H}$-atom treatment

Weighting scheme

$(\Delta / \sigma)_{\max }$

$\Delta \rho_{\max }, \Delta \rho_{\min }\left(\mathrm{e} \AA^{-3}\right)$
(2)

(3)

\begin{tabular}{|c|c|}
\hline $\mathrm{C}_{28} \mathrm{H}_{24} \mathrm{O}_{14} \mathrm{Zn}_{3}$ & $\mathrm{C}_{24} \mathrm{H}_{16} \mathrm{O}_{14} \mathrm{Zn}_{3} \cdot 4 \mathrm{C}_{3} \mathrm{H}_{7} \mathrm{NO}$ \\
\hline 780.58 & 1016.86 \\
\hline Monoclinic, $C 2 / c$ & Monoclinic, $P 2_{1} / c$ \\
\hline $150(2)$ & $100(2)$ \\
\hline $\begin{array}{l}\text { 19.236 (4), } 10.588(2), \\
\quad 16.247(3)\end{array}$ & $\begin{array}{l}12.968(2), 9.761(3), \\
18.336(2)\end{array}$ \\
\hline $90.00,109.109$ (3), 90.00 & $90.00,108.69$ (3), 90.00 \\
\hline $3126.6(10)$ & $2198.7(8)$ \\
\hline 4 & 2 \\
\hline 1.658 & 1.536 \\
\hline Мо $K \alpha, 0.71073$ & Synchrotron, 0.84600 \\
\hline 2.35 & 1.70 \\
\hline Block, colourless & Plate, colourless \\
\hline $0.16 \times 0.15 \times 0.10$ & $0.10 \times 0.04 \times 0.03$ \\
\hline
\end{tabular}

$\mathrm{C}_{11} \mathrm{H}_{11} \mathrm{NO}_{5} \mathrm{Zn}$
302.58
Triclinic, $P \overline{1}$
$150(2)$
$7.9853(18), 8.959(2)$,
$\quad 9.055(2)$
$103.228(3), 100.715(3)$,
$\quad 99.844(4)$
$604.0(2)$
2
1.664
Mo $K \alpha, 0.71073$
2.04
Block, colourless
$0.21 \times 0.14 \times 0.12$

\section{Bruker SMART 1000}

$\omega$ scans

Multi-scan (based on symmetry-related measurements)

0.673

0.791

6736, 2684, 2354

$I>2 \sigma(I)$

0.042

27.6

$F^{2}$
$0.056,0.159,1.17$
2684
165
Constrained to parent site
$w=1 /\left[\sigma^{2}\left(F_{o}^{2}\right)+(0.0772 P)^{2}+\right.$
$\quad 1.7052 P]$, where $P=\left(F_{o}^{2}+\right.$
$\left.\quad 2 F_{c}^{2}\right) / 3$
0.001

\section{Bruker SMART 1000 \\ $\omega$ scans \\ Multi-scan (based on symmetry-related measurements) \\ 0.705 \\ 0.799 \\ 17 033, 3571, 2542}

$I>2 \sigma(I)$
0.091
27.6

$F^{2}$

$0.042,0.102,1.05$

3571

205

Constrained to parent site

$w=1 /\left[\sigma^{2}\left(F_{o}^{2}\right)+(0 P)^{2}+\right.$

5.358P], where $P=\left(F_{o}^{2}+\right.$ $\left.2 F_{c}^{2}\right) / 3$

0.001

$0.63,-0.65$
(4)

\author{
$\mathrm{C}_{48} \mathrm{H}_{38} \mathrm{~N}_{2} \mathrm{O}_{14} \mathrm{Zn}_{3} \cdot 4 \mathrm{C}_{3} \mathrm{H}_{7} \mathrm{NO}$ \\ 1355.30 \\ Monoclinic, $P 2_{1} / n$ \\ 150 (2) \\ 11.777 (4), 14.727 (6), \\ 19.487 (7) \\ 90.00, 101.748 (7), 90.00 \\ 3309 (2) \\ 2 \\ 1.360 \\ Mo $K \alpha, 0.71073$ \\ 1.15 \\ Prism, colourless \\ $0.33 \times 0.29 \times 0.15$
}

$\begin{array}{ll}\begin{array}{l}\text { CCD area detector } \\ \varphi \text { and } \omega \text { scans }\end{array} & \begin{array}{l}\text { Bruker SMART } 1000 \\ \omega \text { scans }\end{array} \\ \begin{array}{l}\text { Multi-scan (based on } \\ \text { symmetry-related } \\ \text { measurements })\end{array} & \begin{array}{c}\text { Multi-scan (based on } \\ \text { symmetry-related } \\ \text { measurements) }\end{array} \\ 0.848 & 0.703 \\ 0.951 & 0.847 \\ 26356,8551,4219 & 36004,7694,4816 \\ & \\ & I>2 \sigma(I) \\ I>2 \sigma(I) & \\ & 0.073 \\ 0.117 & 28.0 \\ 32.2 & \\ & \\ F^{2} & F^{2} \\ 0.064,0.133,0.82 & 0.071,0.207,1.04 \\ 8551 & 7694 \\ 282 & 315 \\ \text { Constrained to parent site } & \text { Constrained to parent site } \\ w=1 /\left[\sigma^{2}\left(F_{o}^{2}\right)+(0.0422 P)^{2}\right], & w=1 /\left[\sigma^{2}\left(F_{o}^{2}\right)+(0.0987 P)^{2}+\right. \\ \quad \text { where } P=\left(F_{o}^{2}+2 F_{c}^{2}\right) / 3 & 5.3224 P], \text { where } P=\left(F_{o}^{2}+\right. \\ & \left.2 F_{c}^{2}\right) / 3 \\ <0.0001 & <0.0001 \\ 1.61,-1.01 & 1.58,-0.93\end{array}$

\section{Experimental}

\subsection{General}

All reagents (purchased from Aldrich) and solvents were used as received. Reactions were performed under autogeneous pressure in a Parr $23 \mathrm{ml}$ pressure vessel equipped with a Teflon liner. Heating and cooling was controlled using a Carbolite programmable oven fitted with a Eurotherm 3216 temperature controller. Elemental analyses were conducted by the Elemental Analysis service, Department of Chemistry, University of Sheffield. Thermogravimetric analysis (TGA) was conducted using a Perkin-Elmer Pyris 1 TGA instrument with heating under $\mathrm{N}_{2}$ at $20 \mathrm{~K} \mathrm{~min}^{-1}$ to $673 \mathrm{~K}$ for (1) and at $10 \mathrm{~K} \mathrm{~min}^{-1}$ to $873 \mathrm{~K}$ for (2).

\subsection{Crystal syntheses}

2.2.1. $\quad \mathrm{Zn}(\mathbf{B D C})$ (DMF) (1). $\quad \mathrm{Zn}\left(\mathrm{NO}_{3}\right)_{2} \cdot 6 \mathrm{H}_{2} \mathrm{O} \quad(0.079 \mathrm{~g}$, $0.26 \mathrm{mmol})$, terephthalic acid $(0.033 \mathrm{~g}, 0.20 \mathrm{mmol})$ and DMF $(8 \mathrm{ml})$ were heated to $373 \mathrm{~K}$, held at this temperature for $24 \mathrm{~h}$ and then cooled to room temperature at $0.1 \mathrm{~K} \mathrm{~min}^{-1}$. Colourless crystals of (1) were isolated from the reaction mixture. Yield: $\quad 0.011 \mathrm{~g} \quad(18.2 \%)$ Calc. for $\mathrm{Zn}\left(\mathrm{C}_{6} \mathrm{H}_{4}\left(\mathrm{CO}_{2}\right)_{2}\right)\left(\mathrm{C}_{3} \mathrm{H}_{7} \mathrm{NO}\right)$ : C 43.66, $\mathrm{H} 3.66, \mathrm{~N} 4.63$; found: $\mathrm{C}$ 42.52, H 3.72, N 5.16\%.

2.2.2. $\mathrm{Zn}_{3}(\mathrm{BDC})_{3}(\mathrm{EtOH})_{2}$ (2). $\mathrm{Zn}\left(\mathrm{NO}_{3}\right)_{2} \cdot 6 \mathrm{H}_{2} \mathrm{O} \quad(0.179 \mathrm{~g}$, $0.60 \mathrm{mmol})$, terephthalic acid $(0.033 \mathrm{~g}, 0.20 \mathrm{mmol}), \mathrm{L}-(-)-$ malic acid $(0.027 \mathrm{~g}, 0.20 \mathrm{mmol})$ and ethanol $(8 \mathrm{ml})$ were heated to $368 \mathrm{~K}$, held at this temperature for $20 \mathrm{~h}$ then cooled to room temperature at $0.1 \mathrm{~K} \mathrm{~min}^{-1}$. Colourless crystals of (2) were isolated from the reaction mixture. Yield $0.031 \mathrm{~g}$ (19.9\%). Calc. for $\mathrm{Zn}_{3}\left(\mathrm{C}_{6} \mathrm{H}_{4}\left(\mathrm{CO}_{2}\right)_{2}\right)_{3}\left(\mathrm{C}_{2} \mathrm{H}_{5} \mathrm{OH}\right)_{2}: \mathrm{C} 43.08, \mathrm{H}$ 3.10; found $\mathrm{C} 43.42, \mathrm{H} 2.51 \%$.

2.2.3. $\quad \mathrm{Zn}_{\mathbf{3}}(\mathrm{BDC})_{3}\left(\mathrm{H}_{\mathbf{2}} \mathrm{O}\right)_{2} \cdot \mathbf{4 D M F} \quad$ (3). $\mathrm{Zn}\left(\mathrm{NO}_{3}\right)_{2} \cdot 6 \mathrm{H}_{2} \mathrm{O}$ $(0.034 \mathrm{~g}, 0.11 \mathrm{mmol})$, terephthalic acid containing $\mathrm{ca} 30 \%$ benzil-4,4-dicarboxylic acid $(0.030 \mathrm{~g}, 0.10 \mathrm{mmol})$ and DMF $(5 \mathrm{ml})$ were heated to $368 \mathrm{~K}$, held at this temperature for $48 \mathrm{~h}$ before being cooled down to room temperature at $0.1 \mathrm{~K} \mathrm{~min}^{-1}$. The small amount of colourless crystalline 
product was collected by filtration. The quantity of product obtained was insufficient to undertake bulk analyses, but yielded a few crystals suitable for single-crystal diffraction study.

2.2.4. $\quad \mathrm{Zn}_{3}(\mathrm{BPDC})_{3}(\mathrm{DMF})_{2} \cdot 4 \mathrm{DMF} \quad$ (4). $\mathrm{Zn}\left(\mathrm{NO}_{3}\right)_{2} \cdot 6 \mathrm{H}_{2} \mathrm{O}$ $(0.079 \mathrm{~g}, 0.26 \mathrm{mmol}), 4,4^{\prime}$-biphenyldicarboxylic acid $(0.048 \mathrm{~g}$, $0.20 \mathrm{mmol})$ and DMF $(8 \mathrm{ml})$ were heated to $373 \mathrm{~K}$, held at this temperature for $24 \mathrm{~h}$ then cooled to room temperature at $0.1 \mathrm{~K} \mathrm{~min}^{-1}$. Colourless crystals of (4) were isolated from the reaction mixture. Yield $0.035 \mathrm{~g}(12.9 \%)$. A number of attempts to obtain satisfactory elemental analysis have proved to be unsuccessful, possibly because of facile solvent loss.

\subsection{Crystallography}

Crystals of (1), (2) and (4) were mounted on glass fibres using a viscous hydrocarbon oil to coat the crystal and then transferred directly to the cold nitrogen stream of an Oxford Cryostream cryostat (for data collection at $150 \mathrm{~K}$ ) on a Bruker SMART 1000 CCD diffractometer operating with a sealedtube X-ray source. X-ray data for (1), (2) and (4) were collected using Mo K $\alpha$ radiation (Bruker AXS Inc., 2003a,b).

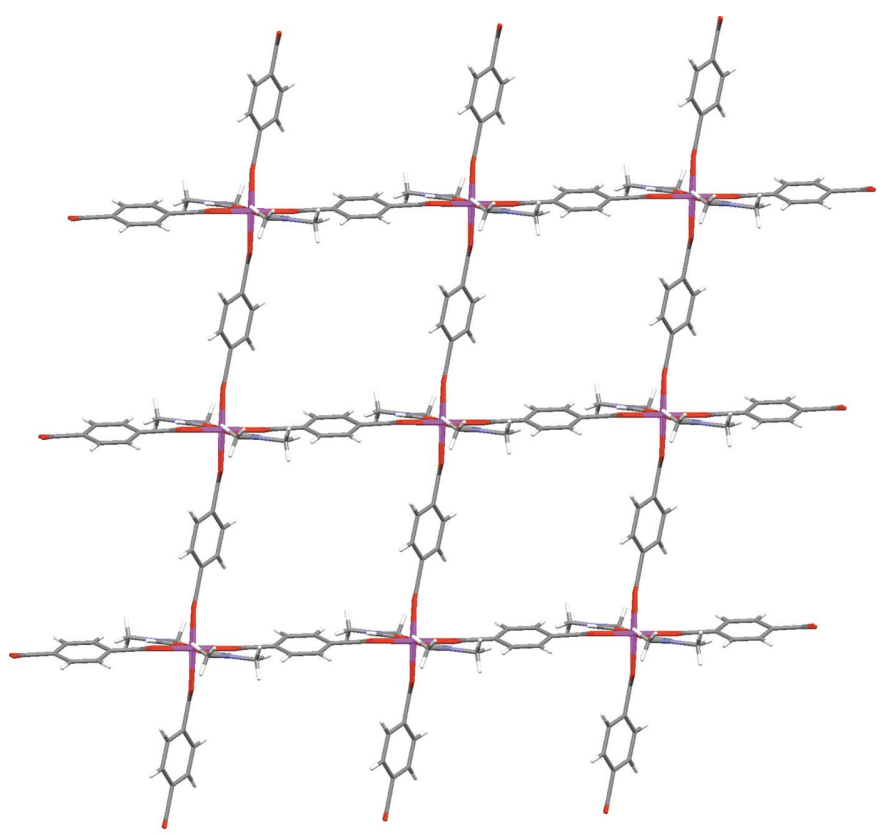

(a)

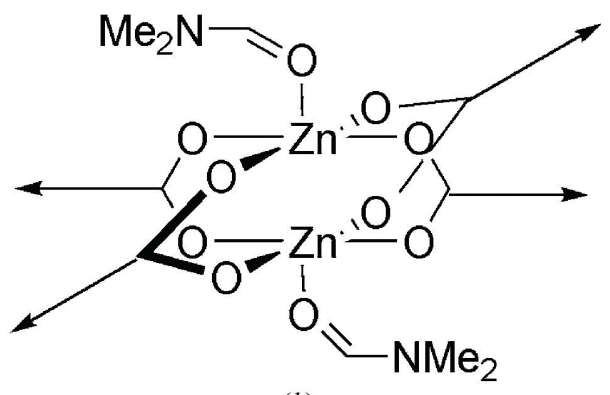

(b)

Figure 1

(a) The two-dimensional square-grid adopted by (1); (b) the $\mathrm{Zn}_{2}\left(\mathrm{CO}_{2}\right)_{4}(\mathrm{DMF})_{2}$ paddle-wheel SBU.
A crystal of (3) was mounted using a similar oil on a thin carbon fibre attached to the end of a borosilicate glass capillary. X-ray data were collected on synchrotron beamline 16.2smx at the SRS at the CCLRC Daresbury Laboratory at $100 \mathrm{~K}$ using a Bruker APEX-II diffractometer equipped with an Oxford Cryostream cryostat. The crystal of (3) was found to be twinned as two domains related by a rotation of $180^{\circ}$ about the $c$ axis. For each compound, data were corrected for absorption using empirical methods (SADABS or TWINABS) based upon symmetry-equivalent reflections combined with measurements at different azimuthal angles (Sheldrick, 1995; Blessing, 1995; Sheldrick, 2002). Crystal structures were solved and refined against all $F^{2}$ values using the SHELXTL suite of programs (Bruker AXS Inc., 1998). Non-H atoms were refined anisotropically (when no disorder was present) and $\mathrm{H}$ atoms associated with $\mathrm{O}$ atoms [in (2) and (3)] were located from the difference map and the $\mathrm{O}-\mathrm{H}$ distance fixed at $0.96 \AA$. All other $\mathrm{H}$ atoms were placed in calculated positions with idealized geometries and refined using a riding model. In (2) the methyl group of the coordinated ethanol solvent molecule is disordered and has been modelled with two orientations in a 71 (2):29 (2) ratio. Refinement of the twin model in (3) indicated an approximately 50:50 twin [0.506 (1):0.494 (1)]. Substantial disorder is present in the structure of (4). Two of the three unique half-ligands of BPDC all have six $\mathrm{C}$ atoms of the phenyl ring and one of the carboxylate $\mathrm{O}$ atoms disordered, and have been modelled in two orientations with a $61.8(6): 38.2$ (6) and $62.9(8): 37.1$ (8) ratio. One of the other carboxylate $\mathrm{O}$ atoms is also disordered over two sites and has also been modelled with a $63.4(6): 36.6$ (6) ratio. The DMF solvent molecules also exhibit disorder. The coordinated DMF molecule has both methyl groups rotationally disordered and these have been successfully modelled in a 72 (2):28 (2) ratio. Of the two uncoordinated DMF molecules, one has both



(a)

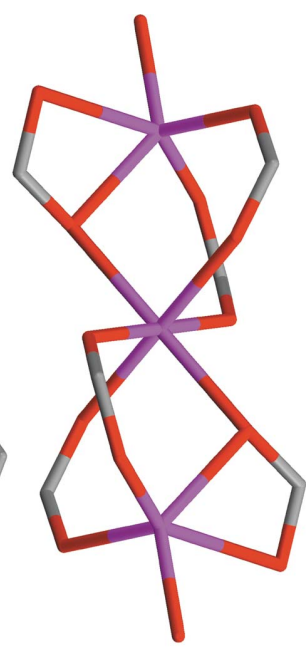

(b)
Figure 2

The trinuclear Zn SBU for (a) (2), (4) and (b) (3) showing the bridging carboxylate groups and the terminal $\mathrm{O}$ atom of a coordinated solvent molecule. The remainder of the dicarboxylic acid and solvent molecule are removed for clarity. $\mathrm{Zn}$ atoms are shown in pink, $\mathrm{O}$ atoms in red and $\mathrm{C}$ atoms in grey. 
methyl groups disordered [in a 52 (1):48 (1) ratio] and the other has both methyl groups and the carbonyl oxygen disordered [modelled with a 53 (2):47 (2) ratio]. A summary of crystal data and structure refinements is provided in Table $1 .^{\mathbf{1}}$

\section{Results}

The reaction of $\mathrm{Zn}\left(\mathrm{NO}_{3}\right)_{2} \cdot 6 \mathrm{H}_{2} \mathrm{O}$ with either terephthalic acid or 4,4'-biphenyldicarboxylic acid under a variety of different solvothermal conditions affords crystals of the two-dimensional metal-organic frameworks (1)-(4). These structures have been characterized using single-crystal X-ray diffraction.

\subsection{Crystal structure of $\mathrm{Zn}(\mathrm{BDC})$ (DMF) (1)}

The structure of (1) is shown in Fig. 1(a) and comprises a two-dimensional square-grid ( $4^{4}$ topology). In this structure, the terephthalate groups bridge between nodes of a $\mathrm{Zn}_{2}(\mathrm{DMF})_{2}$ unit. The overall secondary building unit (SBU) is a $\mathrm{Zn}_{2}\left(\mathrm{CO}_{2}\right)_{4}(\mathrm{DMF})_{2}$ paddle-wheel (Fig. $\left.1 b\right)$.

The asymmetric unit of (1) contains one unique $\mathrm{Zn}^{\mathrm{II}}$ centre, two independent half terephthalate anions and a DMF solvent molecule. The coordination sphere of the $\mathrm{Zn}$ centre comprises four different carboxylate $\mathrm{O}$ atoms as well as the oxygen of a DMF solvent molecule. All $\mathrm{Zn}-\mathrm{O}$ bond lengths fall in the range 1.995 (4)-2.057 (4) $\AA$. Although the $\mathrm{Zn} \cdots \mathrm{Zn}$ distance of 2.951 (1) $\AA$ is indicative of some metal-metal interaction, it is too long to be considered a bond. The channels in the structure of (1) have the dimensions $10.935 \times 10.903 \AA$ (measured between the midpoints of the $\mathrm{Zn}_{2}$ units within four paddlewheels), and are filled by coordinated DMF molecules that protrude into them from layers above and below. TGA analysis of (1) shows that the coordinated DMF solvent molecule is removed (expected loss $22.8 \%$, found $21.4 \%$ ) in the temperature range $383-483 \mathrm{~K}$ and no further weight loss is observed up to $673 \mathrm{~K}$. Confusingly, the TGA trace also shows a weight loss between 328 and $373 \mathrm{~K}$, which can be assigned to the loss of a water molecule [expected loss if formula were $\mathrm{Zn}(\mathrm{BDC})(\mathrm{DMF}) \cdot \mathrm{H}_{2} \mathrm{O} \quad 5.6 \%$, found $\left.5.1 \%\right]$. However, no crystallographic evidence of an incorporated water molecule can be found, which suggests that (1) may have absorbed water from the air.

\subsection{The SBU in structures (2), (3) and (4)}

As previously noted, structures (2), (3) and (4) are isoreticular (Eddaoudi, Kim, Rosi et al., 2002), meaning that they all adopt the same network, in this case one with a $3^{6}$ topology. The SBU for the construction of this $3^{6}$ network in all three structures is the trinuclear $\mathrm{Zn}_{3}\left(\mathrm{O}_{2} \mathrm{CR}\right)_{6}(L)_{2}$ unit $(L=\mathrm{DMF}$, EtOH or $\mathrm{H}_{2} \mathrm{O}$ ), which is shown in Fig. 2.

The $\mathrm{Zn}_{3}\left(\mathrm{O}_{2} \mathrm{CR}\right)_{6}$ SBU contains two crystallographically equivalent four-coordinate terminal $\mathrm{Zn}$ centres [five-coordinate in (3)], to each of which the $\mathrm{O}$ atom of a solvent molecule is axially bonded, and a central six-coordinate $\mathrm{Zn}$ atom. Three

\footnotetext{
${ }^{1}$ Supplementary data for this paper are available from the IUCr electronic archives (Reference: BM5038). Services for accessing these data are described at the back of the journal.
}

dicarboxylate moieties link each pair of $\mathrm{Zn}$ centres, and bridge either using solely monodentate coordination [central $\mathrm{Zn}$ in all structures and terminal $\mathrm{Zn}$ in (2) and (4)] or a combination of monodentate and asymmetric chelating bidentate [terminal $\mathrm{Zn}$ in (3)]. In all cases the central $\mathrm{Zn}$ atom and one of the dicarboxylate ligands lie on inversion centres.

\subsection{Structure of $\mathrm{Zn}_{3}(\mathrm{BDC})_{3}(\mathrm{EtOH})_{2}$ (2)}

The two-dimensional $3^{6}$ network structure of (2) is shown in Fig. 3.

The three $\mathrm{Zn}-\mathrm{O}$ (carboxylate) distances for the terminal $\mathrm{Zn}$ centres lie in the range 1.932 (2)-1.968 (2) $\AA$, whereas for the central $\mathrm{Zn}$ atom they are between 2.057 (3) and 2.096 (2) $\AA$. The separation of the trinuclear units, given by the $\mathrm{Zn} \cdots \mathrm{Zn}$ distance between the central $\mathrm{Zn}^{\mathrm{II}}$ centres in neighbouring SBUs, ranges from 9.696 to $10.588 \AA$. The hydroxyl proton of the coordinated ethanol solvent molecule is involved in the formation of a hydrogen bond to a carboxylate oxygen in an adjacent layer $[(\mathrm{O}) \mathrm{H} \cdots \mathrm{O} 1.77 \AA$; $\mathrm{O}-\mathrm{H} \cdots \mathrm{O} 174^{\circ}$. This results in the formation of an $R_{2}^{2}(8)$ hydrogen-bonded ring (Etter, 1990) linking adjacent trinuclear $\mathrm{Zn}_{3}\left(\mathrm{O}_{2} \mathrm{CR}\right)_{6}$ SBUs, and is shown in Fig. 4.

TGA analysis of (2) shows two distinct mass losses, each of which may arise from the loss of coordinated ethanol solvent molecules, although these mass losses are gradual rather than occurring at a sharply defined temperature. The first is

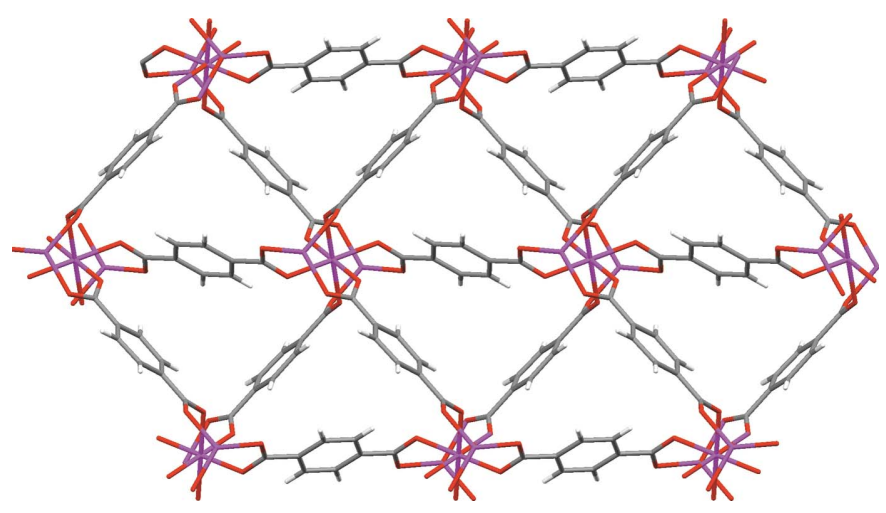

Figure 3

The $3^{6}$ two-dimensional net of (2). Coordinated EtOH solvent molecules are not shown.



Figure 4

The hydrogen bonding linking adjacent layers observed in (3). Only the bridging carboxylate groups of the SBU are shown - the remainder of the terephthalate ligand is removed for clarity. 
observed from $373-428 \mathrm{~K}$ (expected loss $5.9 \%$, found $7.6 \%$ ) and the second loss from 473-598 K (expected 5.9\%, found $6.5 \%)$. The framework then starts to decompose at $628 \mathrm{~K}$.

\subsection{Structure of $\mathrm{Zn}_{3}(\mathrm{BDC})_{3}\left(\mathrm{H}_{2} \mathrm{O}\right)_{2} \cdot 4 \mathrm{DMF}$ (3)}

The crystal structure of (3) has been previously determined at room temperature (Edgar et al., 2001; Zhao et al., 2005), but only a very brief structural description was provided. The lowtemperature structure reported here is described in more detail and in the context of the related structures of (2) and (4). In (3) there are four $\mathrm{Zn}-\mathrm{O}$ (carboxylate) bonds to the terminal $\mathrm{Zn}$ centres, with lengths in the range 1.962 (3) to 2.365 (3) $\AA$. The longest of these distances are the additional asymmetric chelating bidentate bonds shown in Fig. 2(b), which are not present in the structures of (2) or (4). For the central $\mathrm{Zn}$ atom, the $\mathrm{Zn}-\mathrm{O}$ bond lengths lie between 2.038 (3) and 2.166 (3) ̊. As would be expected, the separation of the trinuclear units, in the range 9.761-10.386 $\AA$, is very similar to that observed for (2). The $\mathrm{H}$ atoms of the coordinated water molecules are involved in the formation of hydrogen bonds. Each interacts with the carbonyl $\mathrm{O}$ atoms of a separate DMF solvent molecule $[(\mathrm{O}) \mathrm{H} \cdots \mathrm{O} 1.73,1.80 \AA$; $\mathrm{O}-\mathrm{H} \cdots \mathrm{O} 152,143^{\circ}$ ], as illustrated in Fig. 5. In contrast to (2), these hydrogen bonds do not provide a bridge between adjacent layers. The interlayer spacing in (3) (determined using planes comprising the central $\mathrm{Zn}$ atoms of the $\mathrm{Zn}_{3}$ SBUs) measures $12.285 \AA$, which is considerably larger than

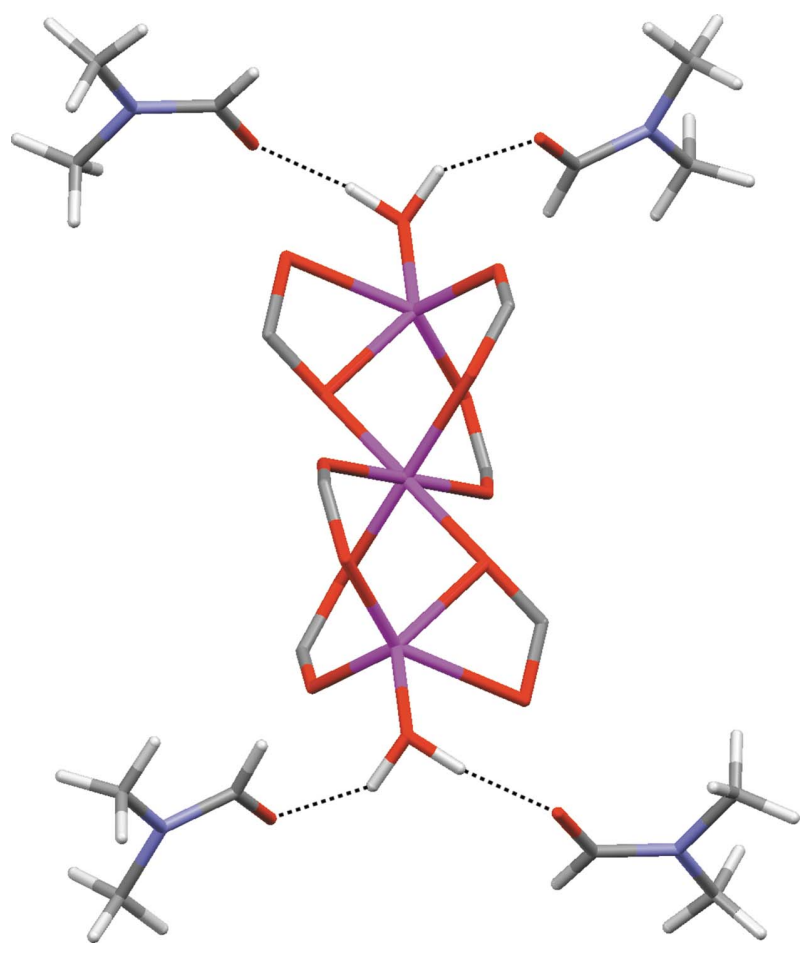

Figure 5

The hydrogen bonding observed in (3) between the coordinated water molecules and incorporated DMF solvent molecules. The remainder of the terephthalate ligands have been removed for clarity. the $9.088 \AA$ for the analogous spacing in (2). This difference can be explained by the fact that (3) contains more solvent molecules per formula unit than (2), despite identical frameworks.

\subsection{Structure of $\mathrm{Zn}_{3}(\mathrm{BPDC})_{3}$ (DMF) $)_{2} \cdot 4 \mathrm{DMF}$ (4)}

The two-dimensional $3^{6}$ network structure of (4) is shown in Fig. 6. In (4) the three $\mathrm{Zn}-\mathrm{O}$ (carboxylate) distances for the terminal $\mathrm{Zn}$ centres lie in the range $1.929(4)-1.948$ (4) $\AA$, whereas for the central $\mathrm{Zn}$ atom they are between 2.009 (11) and 2.088 (5) $\AA$. As would be expected owing to the longer dicarboxylate linker used in (4), the $\mathrm{Zn} \cdots \mathrm{Zn}$ separation between trinuclear SBUs is larger than that seen in (2) and (3) and ranges from 14.394 to $14.727 \AA$. The channels in (4) are filled by disordered free DMF solvent molecules and also by coordinated DMF molecules from adjacent layers.

\section{Discussion}

The $M_{2}\left(\mathrm{O}_{2} \mathrm{CR}\right)_{4}$ paddlewheel moiety is a relatively common SBU for framework construction and it has been applied in the generation of some highly porous materials (Chen et al., 2001; Chui et al., 1999). A number of square-grid framework structures $\left(4^{4}\right.$ networks) related to that in (1) have been previously reported (Takamaizawa et al., 1998, 2000; Braun et al., 2001; Eddaoudi, Kim, Vodak et al., 2002). Several years ago, Yaghi and coworkers described the related two-dimensional framework complex $\mathrm{Zn}(\mathrm{BDC})\left(\mathrm{H}_{2} \mathrm{O}\right) \cdot(\mathrm{DMF})$ ( $\mathrm{Li}$ et al. 1998), which has the same framework as (1) but contains an axially coordinated $\mathrm{H}_{2} \mathrm{O}$ molecule at each $\mathrm{Zn}$ centre rather than the DMF molecule observed in (1). Each water molecule then forms two hydrogen bonds, one to the DMF molecule and a second to the carboxylate $\mathrm{O}$ atom of an adjacent layer to extend the structure along the $a$ axis. The microporosity of this framework was established through the use of $\mathrm{N}_{2}$ and $\mathrm{CO}_{2}$ sorption isotherms, with rapid sorption of these gases into the pores observed. The TGA analysis of this complex is identical



Figure 6

The $3^{6}$ two-dimensional net of (4). Disordered carboxylate $\mathrm{O}$ atoms and DMF solvent molecules (both coordinated and free) are not shown. 
to that observed for (1), with two well separated weight losses. Rather surprisingly, this means that the coordinated water ligands are removed well before the DMF molecules found in the channels. A further report describes the synthesis of a structure analogous to (1), with a DMSO molecule coordinated to the $\mathrm{Zn}$ centre rather than DMF as seen in (1) (Yang et al., 2005). This structure also contains five incorporated DMSO solvent molecules per $\mathrm{Zn}_{2}$ paddlewheel unit. Other reports describe the use of a diamine or diimine linker to join two-dimensional paddlewheel layers. For a comparison with the structure observed in (1), a pair of coordinated DMF solvent molecules in the latter would be replaced by a bridging ligand such as pyrazine, DABCO (1,4-diazabicyclo[2.2.2] octane) or 4,4'-bipyridine. Kim described the framework $\left[\mathrm{Zn}_{2}(\mathrm{BDC})_{2}(\mathrm{DABCO})\right] \cdot 4 \mathrm{DMF} \cdot 0.5 \mathrm{H}_{2} \mathrm{O}$ (Dybtsev et al., 2004), which shows unusual guest-dependent behaviour: the framework shrinks upon inclusion of guest solvent molecules and expands upon release. This study was extended (Chun et al., $2005)$ to include different dicarboxylic acids and diamine or diimine linker molecules, all of which formed structures that adopt the paddlewheel motif. The $\mathrm{H}_{2}$ sorption of this family of complexes was also investigated and a maximum uptake of $2.1 \mathrm{wt} \%$ was observed at $1 \mathrm{~atm} \mathrm{H}_{2}$ pressure. Paddlewheel complexes have also been used in the synthesis of coordination polygons, for example molecular squares (Cotton et al., 2001; Abourahma et al., 2001).

The two-dimensional $3^{6}$ net observed in (2), (3) and (4) is a relatively uncommon structural motif. However, a few examples can be found in the literature, the majority of which involve the $M_{3}$ (terephthalate) $)_{3}$ SBU. Some years ago, Yaghi reported the synthesis and structure of $\left[\mathrm{Zn}_{3}\right.$ (terephthalate $\left.)_{3}(\mathrm{MeOH})_{4}\right] \cdot 2 \mathrm{MeOH}(\mathrm{Li}$ et al., 1998). The structure resembles that of (2) and (3), but the two terminal $\mathrm{Zn}$ centres are each coordinated by two methanol ligands rather than the single ethanol molecule in (2) or the single water ligand present in (3). Uncoordinated $\mathrm{MeOH}$ molecules are also present. Thermal properties of this complex were investigated, as well as the propensity of the evacuated solid to selectively incorporate different alcohols. In the past year we have been aware of six reports of this type of network. Schröder reported the complex $\left[\mathrm{Zn}_{3}(\text { terephthalate })_{3}(\mathrm{DEF})_{2}\right]$.DEF (Williams et al., 2005; where DEF is $N, N^{\prime}$-diethylformamide), in which the coordinated solvent molecules in (2) or (3) are replaced by DEF molecules leaving space for only one uncoordinated DEF molecule per $Z_{3}$ unit. The previous report of the roomtemperature structure of (3) has already been noted (Edgar $e t$ al., 2001; Zhao et al., 2005). Burrows' study of DEF hydrolysis in solvothermal reactions of $\mathrm{Zn}\left(\mathrm{NO}_{3}\right)_{2} \cdot 6 \mathrm{H}_{2} \mathrm{O}$ with terephthalic acid led to the preparation of the compound $\left.\left(\mathrm{NH}_{2} \mathrm{Et}_{2}\right)_{2}\left[\mathrm{Zn}_{3} \text { (terephthalate }\right)_{4}\right] \cdot 2.5 \mathrm{DEF}$, whose structure contains a network of this type (Burrows et al., 2005). However, in this case the two-dimensional $3^{6}$ net is linked to neighbouring layers via additional terephthalate ligands, which coordinate to the axial ligand sites in (2) and (3). A structure containing $\mathrm{Ni}$ rather than $\mathrm{Zn}$ that has the formula $\left.\left[\mathrm{Ni}_{3} \text { (terephthalate }\right)_{3}\left(2,2^{\prime} \text {-bipy }\right)_{2}\right]$ was reported by Jacobson (Go et al., 2005) as part of a systematic study of how the reaction temperature and $\mathrm{pH}$ influence the binding modes of the terephthalate ligand. Two structures containing 2,6-naphthalenedicarboxylate (NDC) have been described by Long (Dincă \& Long, 2005) in their work on complexes for use as $\mathrm{H}_{2}$ storage materials. These have the formulae $\mathrm{Mg}_{3}(\mathrm{NDC})_{3^{-}}$ $(\mathrm{DEF})_{4}$ and $\mathrm{Zn}_{3}(\mathrm{NDC})_{3}(\mathrm{MeOH})_{2} \cdot 2 \mathrm{DMF} \cdot \mathrm{H}_{2} \mathrm{O}$. To our knowledge, (4) is the first occurrence of this $3^{6}$ network using $4,4^{\prime}$-biphenyldicarboxylate as the ligand and leads to a more open framework than with the shorter terephthalate or NDC ligands.

The relatively large difference in interlayer spacing for structures (2) and (3) is indicative of the responsiveness of this framework to flexibility in the spacing between the strongly internally bonded layers, and is presumably important in the solvent desorption and uptake of small alcohols and amines reported by Yaghi and coworkers (Li et al., 1998). This type of dynamic structural transformation is also described in more detail in reviews by Kitagawa (Kitagawa et al., 2004; Kitagawa \& Uemura, 2005).

\section{Conclusions}

The solvothermal synthesis of four two-dimensional metalorganic frameworks containing linear dicarboxylic acids as ligands for $\mathrm{Zn}^{\mathrm{II}}$ centres has been described. All contain coordinated solvent molecules, namely DMF [(1) and (4)], ethanol (2) or $\mathrm{H}_{2} \mathrm{O}$ (3). Structure (1) adopts a common paddlewheel motif leading to a $4^{4}$ grid network, whereas (2), (3) and (4) all form networks with the relatively uncommon $3^{6}$ topology based upon $\mathrm{Zn}_{3}\left(\mathrm{O}_{2} \mathrm{CR}\right)_{6}$ secondary building units. Comparison of structures (2) and (3) illustrates a flexibility in interplanar spacing which is probably related to the ability of this framework to undergo desolvation and uptake of small solvent and gas molecules.

Support from the EPSRC and the University of Sheffield is gratefully acknowledged. We are grateful to Dr Tim Prior at the CCLRC Daresbury Laboratory SRS station 16.2smx for his assistance during the time in which data for (3) were collected.

\section{References}

Abourahma, H., Coleman, A. W., Moulton, B., Rather, B., Shahgaldian, P. \& Zaworotko, M. J. (2001). Chem. Commun. pp. 2380-2381.

Blessing, R. H. (1995). Acta Cryst. A51, 33-38.

Braun, M. E., Steffek, C. D., Kim, J., Rasmussen, P. G. \& Yaghi, O. M. (2001). Chem. Commun. pp. 2532-2533.

Bruker AXS Inc. (1998). SHELXTL5.1. Bruker AXS Inc., Madison, Wisconsin, USA.

Bruker AXS Inc. (2003a). SMART5.040. Bruker AXS Inc., Madison, Wisconsin, USA.

Bruker AXS Inc. (2003b). SAINT6.458/6/03. Bruker AXS Inc., Madison, Wisconsin, USA.

Burrows, A. D., Cassar, K., Friend, R. M. W., Mahon, M. F., Rigby, S. P. \& Warren, J. E. (2005). CrystEngComm, 7, 548-550.

Chen, B., Eddaoudi, M., Hyde, S. T., O'Keeffe, M. \& Yaghi, O. M. (2001). Science, 291, 1021-1023. 
Chui, S. S.-Y., Lo, S. M.-F., Charmant, J. P. H., Orpen, A. G. \& Williams, I. D. (1999). Science, 283, 1148-1150.

Chun, H., Dybtsev, D. N., Kim, H. \& Kim, K. (2005). Chem. Eur. J. 11, 3521-3529.

Cotton, F. A., Lin, C. \& Murillo, C. A. (2001). Acc. Chem. Res. 34, 759-771.

Dincă, M. \& Long, J. R. (2005). J. Am. Chem. Soc. 127, 9376-9377.

Dybtsev, D. N., Chun, H. \& Kim, K. (2004). Angew. Chem. Int. Ed. 43, 5033-5036.

Eddaoudi, M., Kim, J., Rosi, N. L., Vodak, D. T., Wachter, J., O'Keeffe, M. \& Yaghi, O. M. (2002). Science, 295, 469-472.

Eddaoudi, M., Kim, J., Vodak, D., Sudik, A., Wachter, J., O'Keeffe, M. \& Yaghi, O. M. (2002). Proc. Natl. Acad. Sci. USA, 99, 4900-4904.

Eddaoudi, M., Moler, D. B., Li, H., Chen, B., Reineke, T. M., O'Keeffe, M. \& Yaghi, O. M. (2001). Acc. Chem. Res. 34, 319-330.

Edgar, M., Mitchell, R., Slawin, A. M. Z., Lightfoot, P. \& Wright, P. A. (2001). Chem. Eur. J. 7, 5168-5175.

Etter, M. C. (1990). Acc. Chem. Res. 23, 120-126.

Férey, G., Latroche, M., Serre, C., Millange, F., Loiseau, T. \& Percheron-Guégan, A. (2003). Chem. Commun. pp. 2976-2977.

Fujita, M., Kwon, Y.-J., Washizu, S. \& Ogura, K. (1994). J. Am. Chem. Soc. 116, 1151-1152.

Go, Y. B., Wang, X., Anokhina, E. V. \& Jacobson, A. J. (2005). Inorg. Chem. 44, 8265-8571.

James, S. L. (2003). Chem. Soc. Rev. 32, 276-288.

Janiak, C. (2003). J. Chem. Soc. Dalton Trans. pp. 2781-2804.

Kitagawa, S., Kitaura, R. \& Noro, S. (2004). Angew. Chem. Int. Ed. 43, 2334-2375.

Kitagawa, S. \& Uemura, K. (2005). Chem. Soc. Rev. 34, 109-119.
Li, H., Davis, C. E., Groy, T. L., Kelley, D. G. \& Yaghi, O. M. (1998). J. Am. Chem. Soc. 120, 2186-2187.

Li, H., Eddaoudi, M., O'Keeffe, M. \& Yaghi, O. M. (1999). Nature, 402, 276-279.

Lin, W. (2005). Coord. Chem. Rev. 178, 2486-2490.

Noro, S., Kitagawa, S., Kondo, M. \& Seki, K. (2000). Angew. Chem. Int. Ed. 39, 2081-2084.

Rowsell, J. L. C. \& Yaghi, O. M. (2004). Micropor. Mesopor. Mater. 73, 3-14.

Rowsell, J. L. C., Millward, A. R., Park, K. S. \& Yaghi, O. M. (2004). J. Am. Chem. Soc. 126, 5666-5667.

Seo, J. S., Wand, D., Lee, H., Jun, S. I., Oh, J., Jeon, Y. \& Kim, K. (2000). Nature, 404, 982-986.

Sheldrick, G. M. (1995). SADABS. University of Göttingen, Germany.

Sheldrick, G. M. (2002). TWINABS and CELL_NOW. University of Göttingen, Germany.

Takamaizawa, S., Furihata, M., Takeda, S., Yamaguchi, K. \& Mori, W. (2000). Macromolecules, 33, 6222-6227.

Takamaizawa, S., Mori, W., Furihata, M., Takeda, S. \& Yamaguchi, K. (1998). Inorg. Chim. Acta, 283, 268-274.

Williams, C. A., Blake, A. J., Hubberstey, P. \& Schröder, M. (2005). Chem. Commun. pp. 5435-5437.

Wu, C.-D., Hu, A., Zhang, L. \& Lin, W. (2005). J. Am. Chem. Soc. 127, 8940-8941.

Yang, S.-Y., Long, L.-S., Huang, R.-B., Zheng, L.-S. \& Ng, S. W. (2005). Acta Cryst. E61, m1671-m1673.

Zhao, D., Chen, Z., Liu, Z., Sun, J., Weng, L., Yu, T. \& Zhou, Y. (2005). Private Communication to CSD (Refcode: IFACAT01). 